\title{
The role of the ecological culture of the teacher for the sustainable development of the state
}

\author{
N. A. Shaidenko ${ }^{1, *}, S . N$. Kipurova ${ }^{1}, E . V$. Shelispanskaya $^{2}, A . V$. Sergeeva $^{2}$, and $N . Y u$. \\ Zubenko ${ }^{3}$ \\ ${ }^{1}$ Institute for Advanced Studies and Professional Retraining of Educators of the Tula Region, Center \\ for Strategic Education planning the development of education, expertise and scientific consulting, \\ Tula, Russia \\ 2 Tula State Pedagogical University named after L.N. Tolstoy, Tula, Russia \\ ${ }^{3}$ School №. 1080, Moscow, Russia
}

\begin{abstract}
The concept of sustainable development (SD) was born, developed and is actively evolving in many national and international strategies, official reports, modern scientific research in various directions. The context of sustainable development is present in the official and scientific chronicle of the development of society, summarized in documents and studies. However, in pedagogical works, this tendency is not covered in such detail. The idea of SD is aimed at systematic, multidimensional development, at the well-being of countries, peoples, an individual, at eliminating inequalities: demographic, social and political stability and neutralizing factors dangerous for the development of nature. The basic element of SD in the 21 st century is higher education, which was declared at the Paris World Conference on Higher Education in 2009. The evolution of education in a society of sustainable development contributes to a change in the ecological culture of an individual and groups of people based on a value attitude towards nature, safety, health, well-being, unity and cultural diversity. The article is based on the idea of the leading importance of the formed ecological culture of the teacher for the sustainable development of the state. The developed foundations for the formation of environmental culture in the context of sustainable development of university students imply the definition of its goals and conditions, clarification of the structure and relationships between the components, patterns and principles, methods and forms of organization of training, criteria and indicators for assessing the development of components of environmental culture.
\end{abstract}

\section{Introduction}

The concept of the country's transition to sustainable development was approved by the President of Russia in 1996. The concept is designed to ensure a balance in solving social and economic problems and problems of preserving the natural resource potential of the

\footnotetext{
* Corresponding author: nashaidenko@gmail.com
} 
environment, which is necessary to fully meet the needs of the population. In 2015, the UN 2030 Agenda for Sustainable Development was approved.

The main strategic and program documents (doctrines, programs, concepts) of Russia contain activities that involve the implementation of sustainable development goals. "The analysis conducted by the Analytical Center for the Government of the Russian Federation in the spring of 2020, 12 national projects and the Comprehensive Plan for the Modernization and Expansion of the Backbone Infrastructure directly or indirectly affected 107 of the 169 tasks identified in the UN document" [1].

On July 21, 2020, by decree of the President of Russia, the national development goals until 2030 were approved, taking into account which national projects are now being adjusted in the direction of preserving the health and well-being of the population, solving demographic problems in connection with the improvement of the environment. A comfortable and safe environment for life is one of the national goals.

The COVID-19 pandemic and a number of global environmental disasters required the country's leadership to take urgent measures to improve the state of the environment and production technologies in the country, to join efforts with the world community.

On July 19, 2021, a meeting of the Council for Strategic Development and National Projects under the President of the country was devoted to this issue.

President Vladimir Putin introduced a new position of the special representative of the President of the Russian Federation for relations with international organizations to achieve the goals of sustainable development. A.B. Chubais, who believes that a common task with other states can become: "green" topics and sustainable development" [2]. He is convinced that Russia has a big start on sustainable development "thanks to the government, business and civil activists" and that Russia needs to develop a national action plan for sustainable development.

Unfortunately, there is a transfer to the technocratic side of sustainable development and a decrease in the attention of the humanitarian component [3].

The Citizenship Review on the implementation of the Sustainable Development Goals (SDGs) was compiled by the Coalition for Sustainable Development of the Country (CSDC).

"Education for sustainable development (ESD) is mainly of an educational nature (education about, not for, sustainable development) in the form of separate activities, most often environmental. The system of lifelong ESD is not built, there is no regulatory base, the general institutional approach is practically not applied. The global context is poorly represented, which increases the cultural gap between Russia and the world" [4]. In the same document, among the recommendations to the state, the following was given: "Development of the Concept of Education for Sustainable Development and the National Action Plan for 2021-2030. Approval of the state program "Education for Sustainable Development" for 2021-2030 with appropriate funding. Widespread popularization of the concept of sustainable development and SDGs in formal, non-formal (compulsory) and informal education (enlightenment). Preparation and implementation of educational modules on sustainable development for all levels of education and refresher courses for teachers".

The purpose of the study is to substantiate the processes in Russian higher education, which bring it to the world level of training modern teaching staff based on the model of creative, advanced and interdisciplinary education with an orientation towards the tasks of sustainable development of the state. This is an attempt to construct education as a social activity aimed at building a society for sustainable development and the development of a new person through the formation of his ecological culture. 


\section{Materials and Methods}

The development of the problem was carried out at the scientific-theoretical, methodological and experimental-practical levels in a complex system of knowledge, including: the theory of education and pedagogy, psychology of thinking, cultural studies and sociology, ecology and the theory of innovative processes, public policy.

The combination of the principles and methods of scientific knowledge of social phenomena used made it possible to study in dynamics the processes and phenomena that take place in higher pedagogical education that determine the socio-political development of the state and society in dynamics, as well as to identify their influence on the formation of the outlook of a future teacher in the interests of sustainable development of the Russian Federation.

The methodological basis of the study was the following methodological approaches:

- the dialectical approach was used to identify and study contradictions in the processes of changing the functions of the higher pedagogical school in the formation of the worldview of future teachers in the interests of sustainable development of the state in specific historical periods;

- the deductive approach is used to study social phenomena and processes in determining the interdependencies of the development of higher education and sustainable development of the state;

- the inductive approach is used in the transition from specific facts of the transformation of higher education and regulatory documents to characterizing general trends, identifying the objective essence of sustainable development of the state;

- the sociocultural approach made it possible to take into account the changes in society, state and regional characteristics when building the pedagogical process in higher education, aimed at social education, the formation of the ecological culture of students.

The comparative-historical, problem-chronological, retrospective and systemic approaches were used.

The main methods and forms of organizing scientific knowledge were also typologization of the main ideas of sustainable development of the state from the standpoint of the influence of the higher pedagogical school on it.

At the theoretical level, methods of analysis of sociological, political, historical, pedagogical, psychological, etc. were used. research on the problem of sustainable development, higher pedagogical school, environmental culture.

Socio-political analysis was used to study the influence of the socio-political and economic situation on the development of higher education and its influence on the sustainable development of the state, including the formation of the ecological culture of students.

Psychological and pedagogical analysis was applied to assess the effectiveness of the implementation of state educational policy, as well as to study the quality of professional activities of university teachers in the formation of the ecological culture of students in the interests of sustainable development of the state.

Scientific, theoretical and methodological work on the project due to its interdisciplinarity required the use of methods from different fields of knowledge, including: methods of structural and functional analysis, theory of knowledge, didactic analysis of cognitive situations and pedagogical experiment, theory of creative spaces, social anthropology, theory social mobility, social modeling, theory of innovation processes.

Among the empirical methods, methods of included pedagogical observation, polls, testing, conversations, analysis of the results of the formation of ecological culture were used. 
Thus, the solution of the tasks set was carried out on the basis of a comprehensive study of general scientific and specific disciplinary approaches and methods.

\section{Results and Discussion}

"Scientists consider the quality of man's relationship to nature, people, and himself as indicators of the development of his ecological culture. The concept of ecological culture is concretized at each stage of personality development by certain indicators, which is due to the psychological characteristics of age" [5-8].

"A person who has mastered ecological culture subordinates all types of his activities to the requirements of rational nature management, takes care of improving the environment, does not allow its destruction and pollution. Therefore, he needs to master scientific knowledge, master moral value orientations in relation to nature, as well as develop practical skills and abilities to preserve favorable conditions, the natural environment" [9].

The study is based on the original scientific concept that a state needs a new type of social and individual culture of the population for its sustainable development, which can become an ecological culture.

Despite the fact that in scientific research and official documents there is a requirement for the formation of ecological culture, the idea of the conditionality of ecological culture by a new level of development of society and that, in turn, a society of sustainable development can be created only by people with an ecological culture is rarely considered.

The theoretical foundations of the sustainable development of the Russian state were considered in the space of influence on this process of pedagogical education, in particular, the formation of students' ecological culture.

We did not set ourselves the task of conducting a detailed analysis of existing approaches to the structure of ecological culture.

A theoretical analysis of the study of the structure of ecological culture in the works of philosophers, sociologists, psychologists and teachers gave us the opportunity, based on the tasks of a society for sustainable development, to propose the structure of the ecological culture of future teachers in the context of sustainable development, the components of which, interacting with each other, form an integral system:

- motivational and value component;

- cognitive component;

- emotional-volitional component;

- activity-practical component.

Table 1. Characteristics of the levels of formation of the worldview

\begin{tabular}{|c|c|c|}
\hline \multicolumn{3}{|l|}{ Motivational value criterion } \\
\hline High level & Average level & Low level \\
\hline $\begin{array}{l}\text { 1. Always shows a steady } \\
\text { interest in socio-ecological } \\
\text { and other problems of } \\
\text { sustainable development. } \\
\text { 2. Realizes the personal need } \\
\text { to raise the level of knowledge } \\
\text { about the ways to achieve } \\
\text { sustainable development of } \\
\text { Russian society. } \\
\text { 3. The motivation for value- } \\
\text { oriented environmental } \\
\text { activities is at a high level. }\end{array}$ & $\begin{array}{l}\text { 1. Shows interest in socio- } \\
\text { ecological and other problems } \\
\text { of sustainable development. } \\
\text { 2. Has a personal need to raise } \\
\text { the level of knowledge about } \\
\text { ways to achieve sustainable } \\
\text { development of Russian } \\
\text { society; } \\
\text { 3. At the middle level is the } \\
\text { motivation of value-oriented } \\
\text { environmental activities. }\end{array}$ & $\begin{array}{l}\text { 1. Shows no interest in socio- } \\
\text { ecological and other problems } \\
\text { of sustainable development. } \\
\text { 2. There is no personal need to } \\
\text { raise the level of knowledge } \\
\text { about ways to achieve } \\
\text { sustainable development of } \\
\text { Russian society. } \\
\text { 3. The motivation for value- } \\
\text { oriented environmental } \\
\text { activities is at a low level. }\end{array}$ \\
\hline
\end{tabular}


Table 1. Continued

\section{Cognitive criterion}

1. The volume, stability and reliability of knowledge about SD and the possibilities of achieving sustainable development of society are high.

2. Knowledge has passed into stable attitudes and beliefs.

3. Owns the methods of making socially significant and environmentally oriented decisions in professional activities, in the formation of the ecological culture of schoolchildren.

\section{Emotional-volitional criterion}

1. Shows a positive emotional attitude towards nature, environmental and other social issues.

2. Formed readiness for personal and professional selfdevelopment of ecological culture.

3. Has a strong-willed readiness to solve environmental problems in the interests of sustainable development of society.
1. Sufficient volume, strength of socially significant and environmentally oriented knowledge about sustainable development of society.

2. environmental attitudes and beliefs are not sustainable.

3. Shows interest in ways of making socially significant and environmentally friendly decisions in professional activities.
1. Lack of knowledge and understanding of the meaning of the values of sustainable development of society, ignores explanations from others.

2. Occasional manifestations of environmental views and beliefs.

3. Does not show interest in ways of making socially significant and environmentally oriented decisions in professional activity.
1. Shows neutral emotional attitude to nature, environmental and social problems at the regional and global levels;

2. The readiness for personal and professional selfdevelopment of ecological culture is insufficiently formed.

3. Knows how to solve environmental problems for sustainable development.
1. Emotional attitude to nature, economic, environmental and social problems is not formed.

2. The readiness for personal and professional selfdevelopment of ecological culture has not been formed.

3. Does not know how to solve environmental problems in the interests of sustainable development.

\section{Activity-practical criterion}

1. Has experience in environmental activities to change the natural world based on knowledge about sustainable development and ways to achieve sustainable development of Russian society.

2. Knows how to design and implement the ecological culture of the idea of sustainable development in professional and socially significant activities, including the competence of the development of ecological culture.

3. Actively participates in practical, including valueoriented socially significant environmental activities.
1. Does not fully have experience in environmental activities to change the social and natural world on the basis of knowledge about sustainable development and ways to achieve sustainable development of Russian society.

2. Knows how to design, but does not show interest in the embodiment of ecological culture, ideas of sustainable development in professional and socially significant activities.

3. Owns the methods of practical, including valueoriented socially significant environmental activities.
1. Does not have experience in environmental activities to change the social and natural world on the basis of knowledge about sustainable development and ways to achieve sustainable development of Russian society.

2. Does not know how to design and does not show interest in the embodiment of ecological culture, ideas of sustainable development in professional and socially significant activities.

3. Does not know how to practice environmental, including value-oriented socially significant environmental activities. 
Table 1. Continued

\begin{tabular}{|c|c|c|}
\hline \multicolumn{3}{|l|}{ Reflexive-evaluative criterion } \\
\hline $\begin{array}{l}\text { 1. Owns reflexive methods of } \\
\text { assessing his attitudes towards } \\
\text { the natural world and himself } \\
\text { as a part of it. } \\
\text { 2. Able to assess their } \\
\text { readiness to carry out targeted } \\
\text { work to create a society of } \\
\text { sustainable development. } \\
\text { 3. Ready to assess the level of } \\
\text { development of the } \\
\text { components of their } \\
\text { ecological culture in } \\
\text { schoolchildren }\end{array}$ & $\begin{array}{l}\text { 1. Knows reflexive techniques, } \\
\text { ways of assessing his attitudes } \\
\text { towards the natural world and } \\
\text { himself as a part of it. } \\
\text { 2. Sometimes he assesses his } \\
\text { readiness to carry out targeted } \\
\text { work to create a society of } \\
\text { sustainable development. } \\
\text { 3. Insufficiently ready to } \\
\text { assess the level of } \\
\text { development of the } \\
\text { components of ecological } \\
\text { culture. }\end{array}$ & $\begin{array}{l}\text { 1. Does not possess reflexive } \\
\text { techniques, the assessment of } \\
\text { his attitudes towards the } \\
\text { natural world and himself as a } \\
\text { part of it. } \\
\text { 2. Does not assess its own } \\
\text { readiness to carry out targeted } \\
\text { work to create a sustainable } \\
\text { development society. } \\
\text { 3. Not ready to assess the level } \\
\text { of development of the } \\
\text { components of ecological } \\
\text { culture. }\end{array}$ \\
\hline
\end{tabular}

We used general approaches to the essence of the ecological culture of university students from the point of view of the bearer of this culture - the student. Sustainable development cannot be imagined without work on the ecological culture of modern students, which are actively involved in building a new Russian society. It is customary to view the student body as a distributor of a new ideology and culture. That is why young people are the object and subject of national and state interests.

The developed foundations for the formation of environmental culture in the context of sustainable development of university students imply the definition of goals and conditions for formation, clarification of the structure and relationships between the components, patterns and principles, methods and forms of organization of training, criteria and indicators for assessing the development of components of environmental culture.

The goals of the formation of the ecological culture of students in the context of sustainable development in the educational space of a pedagogical university can be expressed through the performance of the following functions by culture: social, educational and creative, upbringing, developing.

The principles of shaping the ecological culture of future teachers in the context of sustainable development are:

- co-evolutionary, which is based on the organization of interaction between man and the natural environment, which in turn influences the formation of the components of ecological culture;

- humanistic, based on the priority of an ecophilic attitude to the natural world, on a positive perception of the World and Nature by a person;

- conformity to nature, based on the correct understanding of the processes occurring in nature;

- cultural conformity.

In general, the direction of the entire system for the formation of ecological culture is set by the following guidelines:

- the main provisions of the humanistic paradigm of training and education;

- anthropocentric approach to teacher training;

- the continuity of the development process of the personality of the future teacher;

- multicultural approach to education;

- the openness of the educational space of the university of social reality by means of pedagogical influence on the subjects of society;

- dialogical nature of interaction with the outside world. 


\section{Conclusions}

As a result of the research:

- the range of criteria and indicators of the effectiveness of the transformation of the systems of higher pedagogical education in Russia has been expanded, aimed at the sustainable co-development of the ecological, economic and social spheres of the states;

- the laws, principles, content, forms, methods and means of transforming the higher education of future teachers in the interests of the sustainable development of the Russian state have been determined;

- the specificity of ecological culture is shown, which consists in the development and assimilation by students of universal human ecological values and norms of behavior, the development of a social ideal in the interests of sustainable development of the state;

- the effectiveness of interdisciplinary and axiological approaches to building the content of education for the ecological culture of future teachers has been proved;

- the tendencies of the formation of the ecological culture of students in the context of the idea of sustainable development of the state are determined;

- substantiations are given for the choice of interactive technologies of the educational process, which activate the development of the ecological culture of students, which will increase the efficiency of the transformation of the systems of training students - future teachers who can contribute to the sustainable development of the Russian state.

The following use of the research results is assumed:

- formation of proposals for state policy in the field of education based on a comparative analysis of modern models of scientific and educational systems and development trends;

- introduction of the developed and tested method of modern research education into the educational process of Russian universities;

- replication of the created scientific and educational model of the innovative educational complex, which ensures the formation of the ecological culture of future teachers;

- development of the state system of full-time and distance learning and tutoring for promising young teachers;

- creation of scientific and methodological manuals for the system of networked scientific and educational training of promising young teachers with an ecological culture in the innovative environment of modern universities.

\section{References}

1. T. Radchenko, K. Bannikova, Rossiyskaya Gazeta, 211 (8265) (2020)

2. A. Chubais, The Russian government has leaped forward in matters of sustainable development, Interview TASS 02/12/2021 (2021)

3. N. Shaidenko, Personality education, 2, 56-60 (2017)

4. 2020-2030: Decade of Action for the SDGs in Russia. Challenges and solutions, 142 (2020)

5. E. Boyarov, S. Abramova, D. GershinkovaSiberian Journal of Life Sciences and Agriculture, 13(1), 111-133 (2021) 
6. L. I. Cvetkova, G. I. Kopina, S.V. Makarova, T. N. Baryshnikova, Water and ecology: problems and solutions, 2(70), 79-89 (2017).

7. V. Golovanov, T. Bykovskaya, N. Panteleeva, S. Fedorova, and A. Tretyakov, Perspectives for Science and Education, 1(49), 299-317 (2021)

8. V. Mezinov, M. Zakharova, I. Karpacheva, Prospects for Science and Education, 1(49), 113-126 (2021)

9. E. Cherdymova, News of the Samara Scientific Center of the Russian Academy of Sciences, 3-1 (2010)

10. N. Shaidenko, N. Zubenko, New psychology of professional work of a teacher: from an unstable reality to sustainable development, 81-85 (2021). 